Brina MALNAR*

\title{
MED AKTUALNIM IN KONCEPTUALNIM: 50 LET AKADEMSKE IZRABE PROGRAMA SLOVENSKO JAVNO MNENJE**
}

\begin{abstract}
Povzetek. Program Slovensko javno mnenje (SJM) deluje že več kot 50 let, a doslej še ni bila opravljena sistematična analiza njegove akademske izrabe. Cilj članka je zapolniti to vrzel in s pomočjo kvantitativne bibliografske študije ovrednotiti infrastrukturno vlogo programa pri produkciji družboslovnih spoznanj. Analiza temelji na 1043 znanstvenih in strokovnih publikacijah za obdobje 1971-2021, ki vsebujejo podatke SJM in so bile pridobljene na različnih spletnih platformah in $v$ fizični obliki. Poglavitna ugotovitev je, da kazalnike SJM uporabljajo raziskovalci $v$ številnih akademskih in drugih organizacijah in na različnih disciplinarnih področjih, pri čemer obravnavajo širok razpon tematik, večinoma $v$ medčasouni perspektivi. Prek 90 arhiviranih datotek SJM predstavlja pomemben del "ekosistema" družboslovnih podatkov $v$ Sloveniji, zgodovinsko gledano pa imajo posebno vrednost kazalniki iz zgodnjega obdobja, ki predstavljajo svojevrstno primerjalno prednost za slovensko empirično družboslovje.

Ključni pojmi: Slovensko javno mnenje (SJM), raziskovalna infrastruktura, uporabniki podatkov, bibliografska študija
\end{abstract}

\section{Uvod}

Socializem in umetnost merjenja političnega javnega mnenja (1968-1991)

Med slovenskimi družboslovci obstaja široko soglasje, da ima program Slovensko javno mnenje (SJM) pomembno infrastrukturno vlogo (Toš, 1999; Malešič, 2013; Adam in Makarovič, 2001; Smrke, 2014; Hafner-Fink, 2016; Močnik, 2018; Mlinar, 2016). Ob pregledu empirično usmerjene domače družboslovne literature bomo na številnih področjih kmalu naleteli

* Dr. Brina Malnar, znanstvena sodelavka, predstojnica Centra za raziskovanje javnega mnenja in množičnih komunikacij, Fakulteta za družbene vede, Univerza v Ljubljani, Slovenija.

** Pregledni znanstveni članek.

DOI: $10.51936 /$ tip.58.3.1065-1088 
na podatke z oznako SJM. Vendar pa doslej še ni bila opravljena širša in sistematična analiza akademske izrabe podatkov SJM, njenega obsega, tematskih poudarkov, disciplinarnih področij in podobno. V naši študiji smo si zadali prav to nalogo, motiv zanjo pa bi lahko opredelili kot samoevalvacijski: po več kot pol stoletja izvajanja raziskav, ko je datotek SJM v podatkovnih arhivih že blizu sto, je nastopil trenutek ko kaže - v duhu programa - empirično raziskati, kakšna je njegova vloga pri pridobivanju spoznanj o družbi.

Da bi študijo postavili v ustrezen kontekst, moramo poznati zgodovino programa, predvsem njegove izhodiščne znanstvene in strokovne cilje in način, kako je definiral in kasneje redefiniral svojo vlogo v slovenskem družboslovnem prostoru. Program SJM se je začel izvajati maja 1968, ko je na teren odšlo prvih 100 anketarjev z imeni in naslovi 2500 prebivalcev Slovenije in vprašalnikom, s katerim je raziskovalna skupina želela meriti "politično javno mnenje«. Tako je bilo zapisano v programsko-organizacijski skici leta 1966 ustanovljenega Centra za raziskovanje javnega mnenja ${ }^{1}$ (CJMMK, 1966a), katerega dejavnost je opredeljena kot "aplikativno-akcijsko raziskovanje«, ki naj se razvija v tesni povezavi s politično sociologijo, je »problemsko orientirano « in naj omogoči »razvojno analizo in demokratično udeležbo občanov v sprejemanju odločitev«, kar bi danes lahko prevedli kot informacijska podpora političnemu odločanju.

Razlog, da si je novi program za svojo temeljno disciplinarno povezavo izbral politično sociologijo, lahko iščemo v tem, da tega področja sistematično ni še nihče pokrival. Sociološke tematike kot so prosti čas, medijske navade, družina, stratifikacija, mladina, trg dela, so v obdobju 60. in 70. let že obravnavale druge empirične raziskave, predvsem na Inštitutu za sociologijo pod vodstvom Jezernika, Bohove, Sakside, Rusa, Hanžka, Mlinarja, Barbičeve, Černigoj-Sadarjeve in drugih (Štebe, 1999: 240-241; Adam in Makarovič, 2002; Saksida, 2016), med njimi je bilo tudi nekaj mednarodnih projektov. Skupina SJM pa je, kot sledi iz programske skice, predvsem ciljala na področje (kontinuiranega) raziskovanja javnega mnenja o »aktualnih političnih in družbenih problemih v Sloveniji«v obliki »letne sondaže«, na raziskovanje »volilnega procesa in obnašanja« ter na naročniške "problemske raziskave« na posameznih področjih družbenega življenja. Ti poudarki dobro napovedujejo vsebino vprašalnikov v prvih, povsem »domačih« 20 letih, saj se je v veliki meri izvajal program, ki je bil tudi napovedan. Spremenil pa se je širši raziskovalni kontekst, saj se obseg prej omenjenih socioloških raziskav v 70. letih ni povečal, prej nasprotno. Tako se z današnje perspektive lahko zdi, da je program SJM v prvem obdobju zanemarjal sociologijo, a te si - z izjemo politične sociologije oziroma presečišča političnih stališč z drugimi tematikami - ni jemal za svoje temeljno poslanstvo.

1 Kasneje preimenovan v Center za raziskovanje javnega mnenja in množičnih komunikacij (CJMMK). 
Ideja o kontinuiranem raziskovanju javnega mnenja $\mathrm{v}$ kontekstu tedanje države ni bila pionirska, nasprotno, zgledovala se je po drugih že vzpostavljenih raziskovalnih centrih $\mathrm{v}$ Jugoslaviji in nekaterih vzhodnoevropskih državah. Kot navaja programska skica Centra za raziskovanje javnega mnenja (CJM), so podobni centri že obstajali v Beogradu v okviru Instituta za družbene vede, v Zagrebu na Institutu za družbene raziskave ter v Sarajevu na Visoki šoli za politične vede, zunaj Jugoslavije pa predvsem na Poljskem. Slovenija je torej v tem smislu že "zamujala in je bila v predlogu za ustanovitev CJM opredeljena kot okolje brez večje tradicije javnomnenjskih raziskav (CJMMK, 1966). Ne glede na omenjeni potencial pa poizkusi povezovanja raziskovalcev podobnih centrov iz Beograda, Zagreba in Ljubljane konec šestdesetih zaradi političnih ovir, konceptualnih razhajanj in finančnih blokad niso uspeli, v sedemdesetih letih pa so ti centri (z izjemo CJMMK) prenehali delovati (Toš, 2010: 125).

Tudi v Sloveniji se je program raziskovanja političnega javnega mnenja kmalu znašel v težavnem odnosu s predstavniki političnega sistema oziroma »vodečih družbenih sil«. To je najbolje razvidno iz dejstva, da ni bilo mogoče slediti predvideni letni dinamiki raziskovanja, saj je bilo v obdobju 1973-1981 izvedenih le pet anket (Toš, 1995: 166). Ob tem člani skupine SJM poročajo tudi o drugih oblikah političnih zapletov, npr.»ideološki kritiki raziskave« v 70. letih, o njeni izključitvi iz »sredstev množičnega obveščanja ${ }^{2}$ (»ko so o izidih raziskav več pisali novinarji iz Zagreba, Beograda kot pa iz Ljubljane«), o poskusih preprečiti zastavljanje nekaterih vprašanj, kot je kmetijski maksimum (ibid.: 167), o "frontalnem napadu " politike zaradi merjenja popularnosti politikov in vodilnega mesta Staneta Kavčiča (ibid.: 171). Gre predvsem za obdobje 70. let, ko je prihajalo tudi do drugih konfliktov med politiko in univerzo, npr. suspenza štirih »ideološko neprimernih" profesorjev na tedanji FSPN (Adam in Makarovič, 2002: 537).

$\mathrm{Na}$ podlagi tega bi lahko ugotovili, da merjenje političnih mnenj v kontekstu avtoritarnega sistema nujno privede bodisi do konfliktov z oblastjo bodisi do konformnosti oziroma do iskanja pragmatičnega ravnotežja med obema. Zdi se, da je bilo oblikovanje vprašalnikov v prvih 15 letih produkt tovrstnega »balansiranja« oziroma iskanja meja "politično možnega«. Kot leta 1995 oceni Toš, "zavestnih kompromisov nismo delali. Šele podrobna analiza celotnega raziskovalnega gradiva v kontekstu časa pa bo pokazala, ali smo se podzavestno izogibali perečim temam« (1995: 167). Vsebine vprašalnika so izhajale iz "profesionalnih interesov ožje raziskovalne skupine in njihove zaznave potreb v znanstvenem in družbenem okolju« (Toš, 1999: 47). Ob tem velja omeniti, da so bili vsi člani ožje ustanovne skupine SJM (tj.

2 Gre za enega od primerov historičnega izrazoslovja, ki se je uporabljalo $v 70$. in 80. letih 20. stoletja in ki je v uvodnem delu članka pogosto prisotno v citatih članov skupine SJM 
Toš, Klinar, Roter, Markič) diplomirani pravniki, ki so se s sociologijo srečali na pravni fakulteti, kjer jo je predaval Jože Goričar, šele nekaj kasneje so se z njo preselila na VŠPV, kasnejši FSPN in zdajšnji FDV. Morda jih je tudi zato na profesionalni ravni zanimal predvsem politični vidik delovanja družbe in, kot navaja Kerševan, sta si z Roterjem že v začetku razdelila področje religije na način, da se je Kerševan ukvarjal z religijo kot sociološkim pojavom (npr. raziskava na vzorcu slovenskih maturantov), Roter pa s cerkvijo v raziskavi SJM, saj so tam "predstavljala težišče aktualna politična vprašanja, ki so ga še posebej zanimala« (Kerševan, 2014).

Po zapletih, do katerih je privedel aktualno politični pristop prvih dveh anket SJM (1968 in 1969), sledi desetletje nerednih raziskav ter manj »izzivalnih"vprašalnikov. Čeprav so bile vsebine še vedno pretežno politične, so se bolj osredotočale na preverjanje nekaterih sistemskih rešitev, npr. politične participacije $v$ t. i. delegatskem sistemu. Ob tem pa so bila potencialno provokativna vprašanja ves čas prisotna, na čelu z vprašanjem o "skladnosti politike ZK z interesi ljudi«, ki je bilo zastavljeno v vsaki raziskavi. A v obdobju gospodarske rasti, večanja realnih dohodkov, zmerne inflacije in zadovoljstva z življenjskim standardom (Mlinar, 1989: 714) je bil visok tudi sistemski konformizem javnosti izmerjen $\mathrm{z}$ anketo.

Po Titovi smrti 1980 je sledil izbruh jugoslovanske gospodarske in politične krize, ki je v nekaj letih $\mathrm{v}$ Sloveniji sprožila tudi proces politične liberalizacije in $s$ tem $z$ vidika SJM vzpostavila bistveno drugačen kontekst raziskovanja. Toš v refleksiji ob 30-letnici programa omenja, kako je v drugi polovici 80. let "popustil pritisk političnega podsistema« in raziskava se je posledično »izraziteje odzvala na pojave $\mathrm{v}$ družbenem in političnem okolju« (1999: 48). To se je odrazilo v močni »aktualizaciji« vprašalnika in hitrih premikih $\mathrm{v}$ javnem mnenju, kar lahko razberemo iz serije intervjujev članov skupine SJM, predvsem za časnik Delo (Toš, 1995). Tako leta 1986 skupina poroča "pesimizmu javnosti glede prihodnosti«, a hkrati o dejstvu, da »skoraj $60 \%$ anketiranih zaupa v sistem socialističnega samoupravljanja« (ibid.: 11). Na novinarsko vprašanje, zakaj je bilo takrat prvič v raziskavo vključeno vprašanje o praznovanju božiča, je član skupine lakonično odgovoril, da so se "tako odločili zato, ker je razprava o božiču postala dovoljena« ter dodal, da božič po ugotovitvah ankete SJM praznuje $79 \%$ anketirancev (ibid.: 19). Taka vprašanja bi bila še kakšno leto prej politično sporna. V tem duhu je bila na primer tudi sprememba formulacije vprašanja o ZK, ki je prej spraševalo o »uresničevanju družbene vloge ZK«, nova verzija pa se je glasila, ali naj bo ZK le ena izmed strank (ibid.: 28).

Poleg aktualnih tematik, ki so zadevale proces demokratizacije, so bile v vprašalniku vse močneje prisotne tudi vsebine, ki jih dandanes prepoznamo kot del procesa osamosvajanja. Tako člani skupine v Delovem intervjuju 1987 poročajo o vse bolj razširjenem mnenju, da bi morala biti 
slovenska nacionalna politika bolj samostojna, da upada »skrajni solidarizem« do nerazvitih delov Jugoslavije, ki je bil »razširjen v evforičnih obdobjih", ter o visoki zaznavi medetničnih razlik v delovnih navadah, kulturi, veri in jeziku (ibid.: 40-41). Ob tem navajajo, da ob sicer "izredno nizkem ugledu Zveze komunistov v slovenski javnosti več kot dve tretjini Slovencev zaupata slovenskemu političnemu vodstvu« (ibid.: 38). Opazimo lahko, da v tem obdobju člani skupine v intervjujih pogosto opuščajo termin »anketiranci« in ga nadomeščajo s »Slovenci«, »Slovenčeva politična kultura«ipd. Leta 1988 Klinar navaja, da je $\$ 58 \%$ ljudi odgovorilo, da obstaja možnost razvoja Slovenije zunaj okvirov Jugoslavije« in da je bilo »lanskih $53 \%$ v tisku kamen velikanske spotike« (ibid.: 57). V tem letu se v vprašalniku pojavi tudi tematika sprave (ibid.: 54).

Med letoma 1989 in 1991 aktualnost in politični angažma vprašalnikov in skupine SJM dosežeta vrhunec. Novinar Dela ugotavlja, da so zdaj »javnomnenjske raziskave priznane, rezultati pa željno pričakovani«, pri čemer je dve raziskavi spremembah ustave naročila tudi slovenska skupščina (ibid.: 84). Novinar Naših razgledov prav tako ugotavlja, da ob Slovenskem javnem mnenju 1990 po medijih »kar frčijo podatki iz raziskave« in da se politika menda kar "puli« zanje (ibid.: 82-84). V tem obdobju podatki kažejo, da "za skoraj polovico Slovencev socializem nima perspektive«, da ZK dojemajo kot le eno od strank, ki naj "razjasni vse povojne napake«, ter da "več kot polovica Slovencev vidi izhod v parlamentarnem sistemu« (ibid.: 69-74). Zdaj si že velika večina "Slovenijo zamišlja kot suvereno državo«, o neuvrščenosti v Slovenčevi politični zavesti pa "ni več sledu« (ibid.: 87-89). Boštjan Markič ob tem ugotavlja, da je minilo obdobje "politične opitosti« v zavesti Slovencev in da je prišlo do »družbenopolitične streznitve«, tj. da je vera v samoupravni socializem splahnela (ibid.: 75).

Za nazaj bi sicer lahko ocenili, da je bilo ravno obdobje osamosvajanja eno od najbolj "politično opitih" obdobij tako v medijih kot v javnosti in v sami skupini SJM, ki je imela do dogajanja v mnogih pogledih manj kritične in tudi politične distance kot prej do socialistične ideologije in oblasti. V intervjuju za Teorijo in prakso leta 1995 Toš pove, da je bil "projekt SJM opazovalec in udeleženec procesa demokratizacije hkrati« ter da si je raziskovalna skupina prizadevala $z$ odpiranjem tem "posegati v te procese" (ibid.: 170). V tej vlogi je imel program SJM gotovo določen »emancipatorni naboj«, z odpiranjem tematik, kot so verbalni delikt, smrtna kazen, vojaščina itd. Prav tako so člani skupine SJM že zgodaj pričeli opozarjati na problematične vidike tega procesa. Tako je Klinar leta $1990 \mathrm{v}$ medijih izjavil, da "Slovencem v njihovem pluralizmu manjka še etnični pluralizem«(ibid.: 90), Toš pa, da je »odnos Slovencev do pripadnikov drugih jugoslovanskih narodov zadržan, z odtenki šovinizma«, kar se v okviru ustavne tematike kaže v težnji po dvigovanju ovir ob dostopu do državljanstva (ibid.: 104). Ugotavlja 
tudi, da se »V zavesti ljudi nesporno izostruje vprašanje solidarnosti in pravičnosti« (ibid.: 102).

Povzamemo lahko, da je bil v obdobju 70. in še bolj 80. let SJM bolj aktualnopolitični »barometer" kot modelska družboslovna raziskava, pri kateri bi bilo primarno merilo tematske selekcije znanstvena, sekundarno pa javnopolitična relevantnosti, tj. produkcija znanstvenih spoznanj za podporo javnim politikam. V nekaterih obdobjih avtorji vprašalnika SJM neposredno soustvarjajo politiko s "sondiranjem" političnih izbir v javnem mnenju, zlasti v ključnih letih demokratizacije in osamosvajanja, in tako vidijo tudi svojo družbeno vlogo.

\section{Iz politične arene $\boldsymbol{k}$ teoretičnim modelom in metodološkim specifikacijam (1991-2020)}

Čeprav smo doslej izpostavljali predvsem aktualno politični vidik, je programska skica CJM iz leta 1966 reflektirala tudi vlogo teorije, saj je v njej zapisno, da »tesna vez raziskovanja na disciplino (teorijo) šele realizira njegove akcijske smotre, omogoča razumevanje bistva pojava ter primerjalno in večstransko analizo problema«. Če je v prvem obdobju program SJM do skrajnosti prignal aktualno politični element svoje »misije«, pa pomeni drugo obdobje postopen, a izrazit prehod $\mathrm{v}$ konceptualno empirično družboslovje.

Leto 1991 je za program SJM prelomno v več pogledih. Kot prvo, ta izgubi svojo ekskluzivno vlogo merilca aktualnega utripa, saj je konec 1991 že povsem zaživela industrija »sondaž" političnega javnega mnenja v agencijah in medijih. Po zaslugi specifičnih zgodovinskih okoliščin in samoohranitvenih "manevrov« raziskovalne skupine je namreč raziskava SJM v dvajsetletnem socialističnem obdobju uspela opravljati to vlogo, s čimer je predstavljala precejšen unikum v kontekstu socialističnega sveta in vzpostavila Slovenijo kot edino državo, ki ponuja možnosti kontinuirane analize "političnega javnega mnenja« v obdobju prehoda. A leta 1992 novinar Naših razgledov ugotavlja, da je skupina SJM ob predstavitvi svoje zadnje raziskave »čeprav $\mathrm{s}$ četrtstoletno tradicijo padla skorajda $\mathrm{v}$ medijsko gluhoto, bohotili pa so se podatki drugih medijskih raziskav" (Toš, 1995: 116). Podatki vsakoletne raziskave SJM se sicer še vedno pojavljajo v medijih, a ne več kot odmevne novice, čeprav so ugotovitve $\mathrm{v}$ kontekstu nove družbene realnosti zelo relevantne. Tako Klinar v intervjujih leta 1992 in 1993 ugotavlja, da se v situaciji "vrednotne anomije ob prehodu v nov sistem poleg liberalnega in egalitarnega oblikuje tudi sklop populističnih vrednot z elementi ksenofobije, naklonjenostjo strožji kaznovalni politiki, povečevanjem socialne distance do marginalnih skupin in odklonilnim odnosom do priseljencev. Toš opozarja na strm upad zaupanja v nove politične institucije, Markič pa ugotavlja, 
da Slovenci politiko vidijo »realno«, tj. kot boj za oblast, delež tistih, ki jo vidijo kot prizadevanje za skupni blagor, je majhen (ibid.: 108-136).

Vprašalnik SJM je še vedno vključeval aktualnopolitične vsebine, npr. strankarske preference, odnos do preteklosti, "aktualne afere kot so bile HIT, Vis, orožje na mariborskem letališču, a ta »barometrski« element se je kmalu pokazal kot provokativen tudi v okoliščinah političnega pluralizma, saj je skupina SJM že 1991 prišla v spor z delom nove politike, ki je njeno lestvico popularnih politikov označil kot »boljševistično« (ibid.: 114). Kot dokazujejo reakcije političnih akterjev v kontekstu obeh družbenih sistemov, dnevnopolitični angažma $\mathrm{v}$ raziskovanje neizogibno vnaša tudi dnevnopolitična tveganja, kar lahko v skrajnem primeru ogrozi celoten program. V tem smislu je bilo dobrodošlo, da se je tradicija aktualnih sondaž leta 1994 preselila v telefonsko raziskavo Politbarometer, čeprav je bila motivacija za to predvsem večja odzivnost raziskav, da bi te lahko sledile tempu komercialnih agencij. Politbarometer je čez dobrih deset let - po odstopu političnega naročnika od pogodbe - ugasnil in od takrat je izrecna aktualnopolitična dimenzija $v$ dejavnosti CJMMK obrobna. Tega seveda ne gre enačiti z možnostjo "angažirane« uporabe podatkov v družbenem prostoru, saj so lahko prav kakovostni podatki o stanju v družbi najbolj zanesljiva podlaga reflektirane kritičnosti. Ta ostaja implicitna ali izrecna perspektiva mnogih družboslovcev (Malešič, 2013), temu nasproten pa je pogled, da pretirana angažiranost prenaša $v$ družboslovje politične delitve in je spoznavno neproduktivna (Adam, 2016). V tem smislu Andolšek govori o - kot kaže nerazrešljivi - razdvojenosti tako domače kot svetovne sociologije na težnjo k objektivizmu in empirični eksaktnosti na eni in usmerjanje k aktivističnemu angažmaju na drugi strani (2016).

Selitev barometrskih vsebin v drug projekt je vsekakor olajšala vstopanje SJM v mednarodne družboslovne programe, kar je drugi prelomni proces, ki se je začel v letu 1991. Takrat se je slovensko empirično družboslovje prek programa SJM hitro vključilo v vse pomembnejše primerjalne ankete, kot so World Values Survey (WVS), European Values study (EVS), International Social Survey Programme (ISSP) in kasneje še European Social Survey (ESS), poleg tega pa še v številne manjše ali občasne projekte. Vključevanje bi bilo lahko še nekaj zgodnejše, a nekatere pobude niso uspele, saj je npr. ISSP zahteval, da se raziskava izvede na celotnem ozemlju Jugoslavije (Toš, 1995: 172). Ne glede na to pa je bila vključitev najbolj obsežna in zgodnja med nekdanjimi socialističnimi državami, še zlasti pa v primerjavi z državami nekdanje Jugoslavije, kjer z delno izjemo EVS za zadnja desetletja ne obstajajo niti približno primerljive časovne vrste. SJM je že imel infrastrukturo, znanje in izkušnje, zato Sloveniji ni bilo treba čakati na vzpostavitve podružnic anketnih multinacionalk in na donatorje, ki bi omogočili, da te agencije družboslovne raziskave tudi izvedejo. Omenjene primerjalne ankete danes veljajo 
za enega poglavitnih virov podatkov o sodobnih družbah (Kuechler, 1998; Mochmann, 2008; Norris, 2009), saj omogočajo analizo dinamike stališč v kontekstu različnih družb in kultur, pri čemer je zlasti spoznavno učinkovita uporaba metode večnivojske analize, (Andreß et. al., 2019; Smith, 2019). Na splošno si danes »težko zamislimo razvoj sodobnega družboslovja brez sistematičnega longitudinalnega in medkulturnega primerjalnega anketnega raziskovanja« (Hafner-Fink, 2016).

Toš ob 30-letnici programa z nekaj nostalgije oceni, da je »bilo raziskovanje v okviru programa SJM do leta 1990 izvirnejše», saj je šlo večinoma za domače operacionalizacije vprašanj, medtem ko se z mednarodnimi povezavami "poudarek preseli na sodelovanje pri operacionalizacijah v mednarodnih teamih ter povečevanje metodološke kakovosti same izvedbe raziskav ter analiz« (Toš, 1999: 54). Tu naj dodamo, da ne gre le za kakovost terenske izvedbe raziskav, čeprav ne gre podcenjevati njene kompleksnosti v mednarodnih družboslovnih anketah. Ta zaradi zagotavljanja ekvivalence postopkov oziroma metodologije zahteva vse večji delovni vložek sodelavcev CJM, ki se nemalokrat "spopadajo « $\mathrm{z}$ desetinami strani izvedbenih protokolov (Jowell et al., 2007), da se slovenski podatki nato »kvalificirajo« za uvrstitev v mednarodno datoteko (Vovk in Kurdija, 2019; Broder in Falle Zorman, 2019).

Enako pomemben vidik je bila analitična kakovost same vsebine vprašalnikov, katerih konstrukcija je v mednarodnih projektih praviloma večleten kooperativen ekspertni proces (Hafner-Fink, 2010). Z vključitvijo v mednarodne programe je v vprašalnike SJM na sistematičen način vstopila vrsta družboslovnih ved, predvsem različne posebne sociologije (religija, družina, delo, prosti časa, zdravje) ter politične vede, ekonomija, ekologija, kriminologija, psihologija in še nekatere. ${ }^{3}$

Ob ekspanziji vsebin iz mednarodnih programov pa v vprašalnikih SJM tudi po letu 1991 ostaja ključna identitetna točka domači blok vprašanj, ki ga je »druga generacija« raziskovalcev po metodoloških in vsebinskih merilih skrajšala na standardno dolžino, s čimer vzdržuje neprekinjeno časovno serijo ključnih kazalnikov. Občasno, največkrat situacijsko, so v vprašalnikih ponovljena tudi druga stara vprašanja (na primer zaznava ekoloških problemov, ugled poklicev, krvodajalstvo ipd.). Omenimo še, da je bila skozi obe obdobji, zlasti pa po letu 1991, vsebina vprašalnikov SJM pogosto tudi rezultat sodelovanja s kolegi in programi na FDV in drugih institucijah, saj je sodeč po kolofonih raziskav pri oblikovanju delov vprašanj poleg ožje programske skupine sodelovalo še okoli 80 raziskovalcev. Po obsegu sodelovanja gotovo izstopa Obramboslovni center s celo serijo anket o odnosu

3 Pregled vsebin je mogoče videti v seriji knjig Vrednote v prehodu, ki so objavljene na domači strani CJMMK (dostopno prek https://www.cjm.si/gradiva/). 
javnosti do nacionalnih in mednarodnih varnostnih struktur (Malešič, 2013; Bebler, 2016), pa Center za prostorsko sociologijo, Center za politološke raziskave, Center za družboslovno informatiko, Center za proučevanje družbene blaginje. Zunaj FDV je bilo najpogostejše sodelovanje s Fakulteto za šport ter Inštitutom za varovanje zdravja, izvajali sta se dve raziskavi Knjiga in bralci ipd.

Kot je bilo nakazano v uvodu, je bil poglavitni namen analize razvoja vsebin vprašalnika in prelomnih točk programa SJM postaviti študijo akademske izrabe podatkov SJM v ustrezen kontekst in omogočiti boljšo presojo znanstvene in strokovne vloge programa $\mathrm{v}$ petdesetletnem obdobju.

\section{Podatki in metoda}

V študijo smo vključili publikacije za obdobje 1968-2021, v katerih avtorji uporabljajo podatke programa Slovensko javno mnenje. Program vključuje celotno paleto raziskav pod oznako SJM, torej raziskave, ki vsebujejo bodisi vprašalnik »Slovensko javno mnenje«, bodisi vprašalnike mednarodnih programov, zlasti WVS/EVS, ISSP in ESS, bodisi kombinacijo obeh. Vse omenjene raziskave so bile izvedene na reprezentativnih nacionalnih vzorcih in so se do leta 2020 izvajale izključno z metodo osebnega intervjuja. V študijo niso vključene publikacije, ki temeljijo na podatkih raziskav centra zunaj programa SJM, predvsem gre za Politbarometer, saj gre za drugačen, naročniški tip raziskave in praviloma za metodo telefonskega intervjuja.

Iskanje publikacij s podatki SJM je potekalo v januarju in februarju 2021 po naslednjih platformah: Google Scholar, Dlib, Cobiss, digitalizirani arhivi revij Teorija in praksa, Družboslovne razprave, Socialno delo in Šport, spletne bibliografije mednarodnih raziskav ter iskanje po fizičnih publikacijah. Na elektronskih platformah, zlasti Google Scholarju, je iskanje potekalo z variacijami večjega števila ključnih besed in besednih zvez, ki v celoti ali delno vključujejo naziv "slovensko javno mnenje« ali kratico SJM, oziroma imena ali kratice štirih poglavitnih mednarodnih raziskav programa (WVS/ EVS, ISSP, ESS). Uporabili smo tako slovenske kot angleške verzije ključnih besed in besednih zvez, v slovenskem jeziku tudi upoštevajoč različne sklone. Prav tako smo uporabili kombinacije nazivov raziskav ter tematskih pojmov (npr. SJM + družbene neenakosti), saj se je izkazalo, da je tako mogoče najti dodatne publikacije.

Minimalni pogoj za vključitev publikacije je bila uporaba vsaj enega podatka SJM. To smo praviloma ugotovili na podlagi dostopa do celotnega besedila, ki smo ga v elektronski ali fizični obliki pridobili za 97\% publikacij, medtem ko smo za 3\% publikacij pridobili del besedila, v glavnem gre za delno dostopne predoglede knjig. Majhno število publikacij (11) je takih, kjer smo na uporabo lahko zanesljivo sklepali iz citatov ali naslova, čeprav 
besedila ni bilo mogoče pridobiti. Nekaj deset potencialno primernih publikacij pa v študijo nismo vključili, ker zaradi nedostopnosti besedila ni bilo mogoče zanesljivo ugotoviti, da uporabljajo datoteke SJM. V analizo tudi nismo vključili več deset raziskovalnih poročil skupine SJM iz zgodnjega obdobja, čeprav so skrbno in kakovostno narejena, saj gre za specifičen tip interne strokovne publikacije, ki se kasneje ne pojavlja več in jo je težko uvrstiti med danes tipične publicistične kategorije.

$\mathrm{Na}$ ta način smo pridobili 1043 ustreznih publikacij, tj. takih, kjer so avtorji bodisi neposredno uporabili datoteke SJM bodisi so navajali podatke iz podatkovnih knjig SJM, v veliki večini iz serije Vrednote v prehodu. Če so podatke citirali le posredno, prek navajanja publikacij drugih avtorjev, enot nismo vključili. Dodatno merilo ustreznost publikacije je bilo, da gre ali za avtorje katerih institucionalni sedež je v Sloveniji ali pa za tuje avtorje, ki so uporabili kazalnike domačega programa SJM. Slovenske datoteke mednarodnih programov, kot so WVS, ISSP, ESS, namreč uporablja na tisoče globalnih avtorjev, a v študiji smo se omejili na publikacije, ki vsebujejo jasen slovenski prispevek, bodisi v obliki domačega avtorstva publikacije bodisi v obliki domačega avtorstva kazalnikov, pogosto seveda tudi oboje. Seznam vseh publikacij je na voljo na domači strani CJMMK (Malnar, 2021).

Na podlagi naslovov, povzetkov in besedil 1043 publikacij smo z ročnim kodiranjem vsebinskih elementov ustvarili bazo bibliometričnih spremenljivk z več modalitetami in podatke vnesli v SPSS-datoteko. Spremenljivke, ki smo jih uporabili v pričujoči študiji, vključujejo: leto izida publikacije, tip publikacije (članek, monografija, poglavje v knjigi, strokovni prispevek, diploma, poročilo), jezik (slovenski, angleški, srbohrvaški), institucionalna pripadnost prvih treh avtorjev (izdelali smo seznam 32 institucij), število avtorjev, (so)avtorstvo članov skupine SJM (da - ne), domicil založnika (Slovenija, bivša Jugoslavija, Vzhodna Evropa, Zahodna Evropa s Severno Ameriko in ostalimi globalnimi založniki), obravnavane tematike (izdelali smo seznam 26 tematik), uporaba posameznih datotečnih letnikov v obdobju 1968-2020 (da - ne), uporaba mednarodnih raziskav (da - ne), prisotnost primerjav z drugimi državami $(d a-n e)$, uporaba makro podatkov $(d a-n e)$, uporabo drugih mikro podatkov ( $d a-n e)$, zahtevnost ravni analize (deskriptivna, napredna), razlogi uporabe več datotek (kombiniranje kazalnikov, medčasovne primerjave, povečevanje vzorca), intenzivnost uporabe podatkov SJM (dominanten vir, enakovreden vir, marginalen vir) ter način citiranja (ime raziskave $v$ besedilu, citat iz podatkovnih knjig, citat datoteke).

Predvidevamo, da smo z delovno intenzivno metodo iskanja pridobili dokaj robusten del publikacij, temelječih pa programu SJM za obdobje 50 let, vsekakor pa ne vseh. Metoda je bila gotovo manj učinkovita za iskanje nekaterih vrst publikacij v zgodnejših obdobjih, saj ta (še) niso ustrezno 
digitalizirana. Tako v prvih obdobjih gotovo manjka velik del diplom, saj se $\mathrm{v}$ repozitorijih pojavi letnik 2000 ali kasnejši. Nasprotno pa ocenjujemo, da smo izsledili večino člankov, saj so digitalni arhivi ključnih družboslovnih revij v glavnem popolni. Problem skozi vsa obdobja so tudi monografije oziroma poglavja $\mathrm{v}$ knjigah, saj te praviloma niso elektronsko dostopne. Predvsem pri knjigah mednarodnih založb smo si deloma pomagali s spletnimi predogledi, ki pa omogočajo le delni uvid v publikacijo. Pri domačih založbah smo se pri tej kategoriji najbolj zanašali na fizične izdaje, saj na CJMMK obstaja precej izčrpna knjižnica publikacij založbe FDV. Če bi želeli vključiti preostale (elektronsko nedostopne) publikacije, bi bil edini način fizični pregled po knjižnicah, kar pa je presegalo možnosti našega delovnega vložka. Omejitve so bile tudi jezikovne, saj so zaradi možnosti preverjanja uporabe podatkov in kodiranja spremenljivk vključene le publikacije v slovenskem, angleškem in srbohrvaškem jeziku. Ocenjujemo, da tu ni prišlo do večjega izpada, saj je velika večina publikacij s podatki SJM objavljenih $\mathrm{v}$ teh jezikih. Čeprav celotne bibliografije programa SJM nismo pridobili pa ocenjujemo, da gre za dovolj velik in reprezentativen del, ki omogoča relevantno analizo analitične izrabe programa SJM.

\section{Rezultati: Študija akademske izrabe programa SJM}

\section{Raba datotek SJM v publikacijah}

Uvodoma nas je zanimal obseg in razpon uporabe datotek SJM, natančneje »datotečnih let«. Zaradi zamudnosti in pogosto nenatančnega navajanja avtorjev, ki bi zahtevalo »detektivsko« razpoznavanje vprašanj, namreč nismo dokumentirali rabe konkretnih datotek, pač pa datotečnih let. Z izjemo prvega obdobja, ko se je izvedla največ ena anketa na leto, je program SJM kasneje letno ustvaril tudi do 5 datotek. Za leta, ko je datotek več, smo tako izračunali zgolj povprečje njihove uporabe, čeprav je verjetno, da raba raziskav istega »letnika« ni enakomerna.

Aktivnih datotečnih let je 46, saj nobena raziskava programa SJM ni bila izvedena v letih 1970, 1974, 1975, 1977, 1979, 1981 in 1985. "Socialističnih" datotečnih let in s tem časovnih točk je 16 (1968-1990), postsocialističnih pa 30. Tabela 1 prikazuje dinamiko produkcije datotek SJM v štirih obdobjih; ker je prvo obdobje daljše, je tu datotek relativno najmanj (21), še zlasti če upoštevamo, da štiri datirajo v leto 1990. Naslednja tri obdobja so polovico krajša, tj. »desetletke", kot omenjeno pa se z letom 1991 prične tudi intenzivni mednarodni program. Skupno je delež datotek, ki vsebujejo (tudi) mednarodne kooperativne projekte, $66 \%$. 
Tabela 1: RABA DATOTEK PO OBDOBJIH

\begin{tabular}{|c|c|c|c|c|c|}
\hline & $\begin{array}{c}1968- \\
1990\end{array}$ & $\begin{array}{l}1991- \\
2000\end{array}$ & $\begin{array}{c}2001- \\
2010\end{array}$ & $\begin{array}{l}2011- \\
2021\end{array}$ & $\Sigma$ \\
\hline Število vseh datotek SJM & 21 & 30 & 24 & 16 & 91 \\
\hline Število datotek z mednarodnim programom* & 0 & 18 & 14 & 14 & 46 \\
\hline Absolutno število rab datotek v publikacijah & 1040 & 1729 & 1152 & 337 & 4258 \\
\hline Povprečno število rab datotek v publikacijah & 49.5 & 58.6 & 48.0 & 21.1 & 46.8 \\
\hline
\end{tabular}

Vir: Lastna raziskava.

*V eni datoteki je pogosto več mednarodnih raziskav, največkrat dva modula ISSP.

Kot lahko vidimo v drugem delu tabele, je bila v povprečju vsaka datoteka SJM v publikacijah uporabljena 47-krat, največkrat datoteke iz obdobja 1991-2000. Nižje povprečje v zadnjem obdobju je predvsem posledica dejstva, da zadnja datotečna petletka še ni publicistično izkoriščena, saj od oddaje datoteke $\mathrm{v}$ arhiv podatkov do njene analitične uporabe in objav izsledkov mine vsaj nekaj let. V standardizirani sliki (povprečje glede na število datotek) se raba posameznih datotečnih let giblje med 28 in 92, pri čemer so največkrat uporabljeni letniki 1980, 1986, 1993, 1998 in 2008.

Razlogov različne "popularnosti« datotečnih let nismo ugotavljali, saj bi to zahtevalo dodatno kvalitativno študijo. Pomemben podatek je, da v $69 \%$ publikacij avtorji uporabijo podatke iz več kot enega datotečnega leta, pri čemer je povprečno število uporabljenih datotečnih let 4, maksimalno pa 25. Poglavitni razlog uporabe več datotek so medčasovne primerjave, ki so prisotne v $57 \%$ publikacij, pomemben razlog pa je še kombiniranje kazalnikov iz več vprašalnikov (37\% publikacij). Po pričakovanju je torej SJM zaradi svoje izrazito dolge časovne vrste epistemološko privlačen kot vir opazovanja dinamike pojavov.

\section{Število, vrsta in jezik publikacij}

Trend števila publikacij glede na vrsto publikacije, jezik in domicil založnika prikazuje Tabela 2. Število publikacij s podatki SJM je v vsakem obdobju višje, od 86 v prvem in najdaljšem do 440 v zadnjem.

Rast števila publikacij je deloma dokaz uspešne uveljavitve in tematske širitve programa, deloma pa gre za splošni pojav določen s širšim kontekstom, tudi globalnim. Z vsakim obdobjem namreč narašča tudi število družboslovnih raziskovalcev in diplomantov, prav tako kot njihova publicistična "produkcija«, zato podobne trende rasti merijo tudi v drugih državah (Malešič, 2013: 278; Hopfenbeck et al., 2018; Kozal et al., 2014).

Med 1043 publikacijami največji delež predstavljajo znanstveni članki (45\%), ki so v vseh obdobjih najštevilčnejša kategorija. Strokovni prispevki si bili značilni predvsem za prvo obdobje, ko so člani skupine SJM aktualne 
rezultate $\mathrm{v}$ kratkih strokovnih člankih objavljali v Teoriji in praksi, katere glavni urednik je bil v obdobju 1988-1994 Boštjan Markič. Kot rečeno, je delež diplomskih del pred letom 2000 zaradi pomanjkljive digitalizacije gotovo podcenjen, kasneje pa se pojavljajo v četrtinskem deležu. Največji deleži monografij so v obdobju 1991-2010, zadnje desetletje pa se poudarek seli na članke, kar je praviloma povezano z načini vrednotenja znanstvenega dela tako v nacionalnem kot mednarodnem kontekstu.

Tabela 2: ŠTEVILO, VRSTA IN JEZIK PUBLIKACIJ

\begin{tabular}{|l|c|c|c|c|c|}
\hline & $\begin{array}{c}1968- \\
\mathbf{1 9 9 0}\end{array}$ & $\begin{array}{c}\mathbf{1 9 9 1 -} \\
\mathbf{2 0 0 0}\end{array}$ & $\begin{array}{c}\mathbf{2 0 0 1 -} \\
\mathbf{2 0 1 0}\end{array}$ & $\begin{array}{c}\mathbf{2 0 1 1 -} \\
\mathbf{2 0 2 1}\end{array}$ & $\Sigma$ \\
\hline Število najdenih publikacij s podatki SJM & 86 & 151 & 366 & 440 & 1043 \\
\hline \% delež znanstvenih člankov & 44.2 & 51.0 & 37.7 & 49.5 & 45.2 \\
\hline \% delež knjig in poglavij & 7.0 & 29.1 & 30.9 & 16.6 & 22.6 \\
\hline \% delež strokovnih prispevkov & 43.0 & 16.6 & 5.8 & 5.9 & 10.5 \\
\hline \% delež diplomskih del & 0.0 & 0.7 & 20.5 & 23.9 & 17.4 \\
\hline \% delež poročil* & 5.8 & 2.6 & 5.2 & 4.1 & 4.4 \\
\hline \% delež znanstvenih člankov v angleščini & 10.5 & 27.3 & 36.2 & 56.9 & 42.3 \\
\hline \% delež vseh publikacij v angleščini & 4.7 & 23.2 & 30.3 & 42.7 & 32.4 \\
\hline \% publikacij s tujim založnikom & 7.0 & 14.8 & 25.2 & 30.5 & 24.4 \\
\hline
\end{tabular}

Vir: Lastna raziskava.

*Gre za poročila zunanjih uporabnikov z vključitvijo podatkov SJM, ne poročila programa financerjem SJM.

Prav tako je od meril vrednotenja izrazito odvisen delež publikacij v angleškem jeziku, ki je v vsakem obdobju višji, še zlasti pri znanstvenih člankih. Čeprav večina teh publikacij izide pri tujih založnikih, raste tudi delež angleških besedil v domačih revijah in monografijah (Grizold, 2014: 1020). Trend internacionalizacije seveda ni posebnost publikacij SJM, prisoten je v celotnem družboslovju v številnih državah (Kulczycki, 2018; Engels et al., 2012). Ima tako dobre plati, npr. vidnost in neposredna vpetost v mednarodno produkcijo znanja, kot slabe, npr. manjša dostopnost delu domače strokovne javnosti, tudi simbolno razvrednotenje oziroma vnaprejšnje podcenjevanje objav v domačem jeziku (Bernik, 2016; Adam, 2016).

\section{Organizacijska pripadnost avtorjev}

Z vidika ocene infrastrukturne vloge programa in načrtovanja komunikacije z uporabniki je bil eden pomembnejših ciljev študije ugotoviti, iz katerih akademskih organizacij prihajajo avtorji publikacij SJM. V Tabeli 3 je prikazan institucionalni izvor prvega avtorja in glede na to, da ima $69 \%$ publikacij le enega avtorja, nadaljnjih $20 \%$ pa dva, ki v veliki večini prihajata 
iz iste institucije, se to zdi ustrezen približek slike organizacijske pripadnosti.

Tabela 3: ORGANIZACIJSKA PRIPADNOST PRVIH AVTORJEV (DELEŽI V\%I)

\begin{tabular}{|l|c|c|c|c|c|}
\hline & $\begin{array}{c}\mathbf{1 9 6 8 -} \\
\mathbf{1 9 9 0}\end{array}$ & $\begin{array}{c}\mathbf{1 9 9 1 -} \\
\mathbf{2 0 0 0}\end{array}$ & $\begin{array}{c}\mathbf{2 0 0 1 -} \\
\mathbf{2 0 1 0}\end{array}$ & $\begin{array}{c}\mathbf{2 0 1 1 -} \\
\mathbf{2 0 2 1}\end{array}$ & $\boldsymbol{\Sigma}$ \\
\hline Fakulteta za družbene vede UL & 83.7 & 70.7 & 57.8 & 48.4 & 57.8 \\
\hline Druge fakultete UL & 11.6 & 14.7 & 15.6 & 17.1 & 15.8 \\
\hline Univerza v Mariboru & 0.0 & 1.3 & 7.4 & 14.2 & 8.8 \\
\hline Druge institucije v Sloveniji* & 4.7 & 10.7 & 15.3 & 15.8 & 14.0 \\
\hline Institucije v tujini & 0.0 & 2.7 & 3.8 & 4.6 & 3.7 \\
\hline \hline (So)avtorstvo članov skupine SJM & 47.7 & 33.1 & 14.8 & 10.9 & 12.8 \\
\hline
\end{tabular}

Vir: Lastna raziskava, $\mathrm{N}=1043$ publikacij;

*Univerze, inštituti, vladne in nevladne organizacije, druge organizacije.

Daleč največji delež prvih avtorjev prihaja iz FDV, skupno skoraj 58\%, a se skozi obdobja ves čas zmanjšuje, saj se krog uporabnikov in njihovih institucij močno razširi (podroben prikaz je v Prilogi 1). Tako v zadnji desetletki FDV predstavlja le še relativno večino prvih avtorjev, opazen pa je na primer izrazit porast rabe podatkov na Univerzi v Mariboru, kjer na filozofski in varnostni fakulteti obstajata dve močni skupini uporabnikov. Raste tudi uporaba v drugih institucijah v Sloveniji, kar je z vidika infrastrukturne vloge programa ugoden trend. Delež avtorstev ožje skupine SJM je do leta 1990 visok, deloma tudi zaradi neposrednega dostopa do datotek v obdobju, ko še ni bilo javnih arhivov, kot je danes ADP (Štebe in Bezjak, 2017), in so zunanji uporabniki prišli do podatkov predvsem prek poročil. Del upada notranjih publikacij gre tudi na račun dejstva, da sta leta 1994 preminila dva publicistično zelo aktivna člana izvorne skupine, tretji pa se je publicistično upokojil.

\section{Akademske skupnosti uporabnikov}

Kot smo videli iz programske skice, se je program SJM disciplinarno umestil na presečišče sociologije in politologije, kar sta tudi daleč največji skupini akademskih uporabnikov (Tabela 4). Slika njihove disciplinarne pripadnosti je sicer posredna in približna, saj smo jo dobili na podlagi področja revije, kjer so objavljeni znanstveni in strokovni članki. Politične vede prevladujejo tudi zaradi kategorizacije TiP na politološko področje (Mlinar, 2004: 11-12), saj precejšen delež publikacij izhaja iz "hišne« revije FDV, v kateri pa seveda objavlja tudi veliko sociologov. Iz podatkov tako sledi predvsem, da so analitiki s področja političnih ved, vključno z obramboslovjem, ter socioloških ved, vključno z družboslovno metodologijo, 
primarna skupina akademskih porabnikov programa SJM, kar je pričakovano. Pomembnejši deleži uporabnikov prihajajo še s področja medicine in zdravstva ter deloma ekonomije.

Tabela 4: PODROČJA REVIJ ZNANSTVENIH IN STROKOVNIH ČLANKOV $(N=520 \check{C L A N K O V)}$

\begin{tabular}{|l|c|c|}
\hline Področje revije & $\begin{array}{c}\text { število } \\
\text { člankov }\end{array}$ & \% delež \\
\hline Politične vede & 210 & 40.4 \\
\hline Sociologija & 173 & 33.3 \\
\hline Zdravje, medicina, šport & 32 & 6.2 \\
\hline Metodologija & 30 & 5.8 \\
\hline Ekonomija & 20 & 3.8 \\
\hline Multidisciplinarna & 11 & 2.1 \\
\hline Okolje & 11 & 2.1 \\
\hline Varnost, obramba & 10 & 1.9 \\
\hline Drugo* & 23 & 4.2 \\
\hline
\end{tabular}

Vir: Lastna raziskava; *mediji, IKT, psihologija, pravo, demografija.

\section{Obravnavane tematike}

Mnogo podrobnejši uvid v disciplinarno raznolikost izsledkov nam da pregled obravnavanih tematik. Ker je program SJM splošnega tipa in vključuje veliko število vsebinskih sklopov, nas je predvsem zanimalo, kakšen je razpon obravnavanih tematik in kje so poudarki. V Tabeli 5 je strnjen prikaz za celotno obdobje in vključuje 26 vsebinskih sklopov, razpoznanih v procesu ročnega šifriranja 1043 publikacij.

Glede na politično-sociološko zastavitev programa in iz nje izhajajočih vsebin vprašalnikov ni presenetljivo, da so na prvem mestu politične tematike, ni pa to edini razlog. Te enako prepričljivo prevladujejo tudi med publikacijami European Social Survey (Malnar, 2020: 8) in preprosto predstavljajo eno ključnih raziskovalnih problematik vsake družbe, saj vključujejo vidike legitimnosti (demokratičnih) sistemov, politične participacije, političnih stališč, populizma itd. Druga najpogosteje obravnavana vsebina pa je regionalno specifična, razpad Jugoslavije in (post)tranzicija, kar nakazuje, da je bil SJM pomemben podatkovni vir za refleksijo tega procesa. $\mathrm{Na}$ tretjem mestu je področje religije, kar je deloma posledica interesa piscev same skupine SJM za to tematiko, predvsem pa obstoja nekaj močnih raziskovalnih skupin in analitikov na obeh največjih univerzah, za katere program SJM predstavlja poglavitni vir podatkov. 
Tabela 5: ANALITIČNE TEMATIKE V PUBLIKACIJAH SJM

$(N=1043$ PUBLIKACIJ)*

\begin{tabular}{|l|c|}
\hline Tematika & $\begin{array}{c}\text { Stevilo } \\
\text { publikacij }\end{array}$ \\
\hline Politični sistem, participacija, stranke, volitve, demokracija, EU & 185 \\
\hline Razpad(anje) Jugoslavije, osamosvajanje, (post)tranzicija & 130 \\
\hline Religija, cerkev, religioznost, denominacije & 100 \\
\hline Zdravje, zdravstveni sistem, zdravstveni delavci & 93 \\
\hline Priseljenci, etnične manjšine, begunci, nestrpnost & 82 \\
\hline Vrednote, kultura, dinamika vrednot & 71 \\
\hline Delo, zaposlitev, delovna etika, mobing, sindikati, socialni dialog & 65 \\
\hline Obramba, varnost, vojska, NATO, terorizem, naravne nesreče & 60 \\
\hline Starostne skupine (mladi, stari), medgeneracijski odnosi & 58 \\
\hline Spol, spolne neenakosti, seksizem, splav & 52 \\
\hline Sodstvo, policija, kriminaliteta, smrtna kazen, korupcija & 50 \\
\hline Prosti čas, življenjski slog, kultura, šport & 49 \\
\hline Ekonomija, recesija, ekonomske organizacije, ekonomske vrednote & 48 \\
\hline Okolje, okoljska zavest, jedrske elektrarne & 47 \\
\hline Socialne politike, blaginjski sistem, odnos do redistribucije, UTD & 45 \\
\hline Nacionalna identiteta, zgodovina, osebnosti, jugonostalgija & 45 \\
\hline Metodologija, vzorčenje, kazalniki & 42 \\
\hline Množični mediji, digitalna omrežja, informacijska družba & 41 \\
\hline Družina, starševstvo, družinske vloge, ravnotežje delo-družina, ločitev & 41 \\
\hline Izobrazba, izobraževanje, šolstvo, znanost, učitelji & 39 \\
\hline Družbene neenakosti, mobilnost, stratifikacija, razredi & 38 \\
\hline Spolne in druge ne-etnične manjšine, lgbt, diskriminacija & 35 \\
\hline Prostor, mobilnost, lokalna skupnost, bivanje, globalizacija & 32 \\
\hline Socialni kapital, zaupanje soljudem, omrežja & 28 \\
\hline Državljanstvo, civilna družba, prostovoljstvo, NVO & 24 \\
\hline Sreča, subjektivna blaginja & 23 \\
\hline
\end{tabular}

Vir: Lastna raziskava; *vsaka publikacija je lahko dobila do dve tematski šifri.

Sledi še 23 tematik iz širokega razpona družboslovnih raziskovalnih področij, na čelu z zdravjem, imigracijami in vrednotami. Poleg pogoste uporabe podatkov SJM med avtorji iz zdravstvenega področja (zlasti prvih meritev deleža kadilcev na nacionalni populaciji v 70. letih), je precej publikacij na temo zdravja nastalo tudi znotraj skupine SJM. Podobno velja za tematiko vrednot, medtem ko se je analiza tematike migracij, ki je bila $s$ Klinarjem izvorno »domicilna"v skupini SJM in na FDV, kasneje vse bolj selila na druge akademske ustanove, zlasti na inštitute.

Povzamemo lahko, da je slika analiziranih tematik deloma odraz vsebine domačih in mednarodnih vprašalnikov SJM in deloma odraz interesa in velikosti posameznih akademskih skupnosti v Sloveniji. Z vidika infrastrukturne vloge programa pomeni potrditev, da ta omogoča obravnavo 
Širokega razpona raziskovalnih vprašanj, z vidika produkcije znanja pa bi bilo vsekakor zanimivo opraviti sistematični pregled publikacij na posameznih področjih in povezati izsledke.

\section{Strategije navajanja in analize podatkov}

V sklepnem delu nas je zanimalo nekaj vidikov analitičnih pristopov in citiranja podatkov. Zlasti za prvi dve desetletji sta značilni pretežno esejistična kultura pisanja in neizkušenost večine avtorjev z empiričnimi članki, prav tako niso bila izdelana pravila navajanja datotek. Kot omenjeno, takrat še niso obstajali javni arhivi; tudi zato, da bi podatke približali uporabnikom, je na CJM leta 1997 pričela izhajati serija knjig Vrednote v prehodu, ki v zadnjih dveh obdobjih, sodeč po navajanju, predstavlja vir podatkov za petino publikacij (Tabela 6). Tabela sicer nazorno kaže uveljavljanje norme navajanja podatkov, saj je viden močan upad prve modalitete, ki jo lahko opredelimo kot najšibkejši način citiranja in skok zadnje, ki v idealnem primeru predstavlja poln citat iz arhiva podatkov. Značilna je predvsem za avtorje, ki uporabijo datoteke SJM za lastne obdelave, medtem ko podatkovne knjige citirajo avtorji, ki teh obdelav ne potrebujejo.

Tabela 6: SLOGI NAVAJANJA PODATKOV SJM ( $N=965$ PUBLIKACIJ, DELEŽI V\%)

\begin{tabular}{|l|c|c|c|c|c|}
\hline & $\begin{array}{c}1968- \\
1990\end{array}$ & $\begin{array}{c}1991- \\
\mathbf{2 0 0 0}\end{array}$ & $\begin{array}{c}\mathbf{2 0 0 1 -} \\
\mathbf{2 0 1 0}\end{array}$ & $\begin{array}{c}\mathbf{2 0 1 1 -} \\
\mathbf{2 0 2 1}\end{array}$ & $\Sigma$ \\
\hline Ime (in leto) raziskave SJM v besedilu & 91.9 & 72.5 & 50.3 & 26.2 & 47.2 \\
\hline Citat podatkovnih knjig skupine SJM & 1.2 & 3.5 & 21.1 & 26.4 & 19.0 \\
\hline Citat datoteke & 7.0 & 23.9 & 28.6 & 47.4 & 33.9 \\
\hline
\end{tabular}

Vir: Lastna raziskava.

Kot vidimo v Tabeli 7, je po letu 2000 bistveno narasel delež publikacij, kjer je poleg SJM uporabljen še kakšen vir mikro podatkov, prav tako narašča uporaba makro kazalnikov.

Tabela 7: VIDIKI ANALITIČNIH STRATEGIJ V PUBLIKACIJAH SJM

( $N=965$ PUBLIKACIJ, DELEŽI V\%)

\begin{tabular}{|l|c|c|c|c|c|}
\hline$\%$ & $\begin{array}{c}\mathbf{1 9 6 8 -} \\
\mathbf{1 9 9 0}\end{array}$ & $\begin{array}{c}\mathbf{1 9 9 1 -} \\
\mathbf{2 0 0 0}\end{array}$ & $\begin{array}{c}\mathbf{2 0 0 1 -} \\
\mathbf{2 0 1 0}\end{array}$ & $\begin{array}{c}\mathbf{2 0 1 1 -} \\
\mathbf{2 0 2 1}\end{array}$ & $\Sigma$ \\
\hline Prisotnost drugih mikro podatkov & 18.6 & 29.7 & 46.6 & 49.9 & 43.2 \\
\hline Prisotnost makro podatkov & 20.9 & 25.7 & 45.6 & 49.7 & 42.4 \\
\hline Uporaba zahtevnejših metod v člankih* & 2.6 & 13.9 & 19.0 & 22.0 & 18.3 \\
\hline Mednarodne primerjave & 0.0 & 15.5 & 21.5 & 23.4 & 19.7 \\
\hline
\end{tabular}

*regresija, faktorska analiza, cluster analiza, indeksi ipd. ( $N=465$ člankov).

Vir: Lastna raziskava 
To nakazuje, da je bila v prvem obdobju gostota vseh vrst podatkovnih virov manjša, deloma pa gre verjetno tudi za širjenje "podatkovne kulture« pisanja v družboslovju, pri kateri analitiki vse bolj uporabljajo širši »ekosistem" empiričnih kazalnikov, kar po pričakovanju poveča veljavnost in robustnost analize. Ob tem smo s pregledom publikacij ugotovili, da je $\mathrm{v}$ $41 \%$ SJM edini ali ključni vir podatkov, v $40 \%$ enakovredni vir, v 19\% pa obrobni. Ugotovili smo še, da so avtorji v $69 \%$ publikacijah uporabili več kot tri kazalnike iz datotek SJM.

Glede na to da je $\mathrm{v}$ zadnjih dveh desetletjih $\mathrm{v}$ programu SJM izrazit poudarek na kakovosti metodološke izvedbe in konceptualizaciji vprašalnikov, so nas z vidika izrabe tega potenciala zanimali tudi analitični pristopi avtorjev. Ena od strategij za povečanje spoznavne učinkovitosti analize kvantitativnih podatkov je namreč tudi uporaba zahtevnejših statističnih metod, zlasti metod modeliranja, ki jih skozi teoretično zasnovo vprašalnikov tematsko podpirajo predvsem številne mednarodne datoteke programa SJM. Ta trend smo opazovali le na podskupini člankov kot znanstveno najbolj rigorozni vrsti publikacije. Opazen je dokajšen skok uporabe zahtevnejših metod po letu 1991 in nato zmerna rast - v zadnjem obdobju takšne publikacije predstavljajo 22-odstotni delež.

Upoštevajoč intenzivnost mednarodnega programa v SJM nas je ob tem zanimalo, v kolikšni meri avtorji Slovenijo (po letu 1991) analitično postavljajo v primerjalno perspektivo. Kot je razvidno iz Tabele 7, je v zadnjem obdobju 23\% publikacij takih, kjer so prisotne primerjave Slovenije z drugimi državami, skupno pa 203. Tega deleža ne gre enačiti s celotnim obsegom uporabe podatkov iz mednarodnega programa SJM, ki je bistveno višji, saj pretežni del avtorjev uporabi le. slovenske podatke datotek ISSP, ESS ipd. Ob naraščajočem deležu primerjalnih publikacij pa je pregled njihovih besedil pokazal, da je uporaba danes najbolj cenjene tehnike primerjalnega modeliranja - večnivojske regresijske analize - skorajda zanemarljiva. Nasprotno pa bibliografska analiza 2100 znanstvenih člankov s podatki raziskave ESS $\mathrm{v}$ mednarodnih revijah razkrije, da jih kar 34\% uporablja to tehniko modeliranja (Malnar, 2020: 9), v ostalih primerih pa večinoma druge oblike regresije. Seveda ni mogoče pričakovati, da bi bilo podobno na nacionalni ravni, a po mnenju številnih metodologov je pomanjkljivo znanje analitičnih tehnik v domačem družboslovju precejšen problem, tudi kot posledica zmanjševanja obsega teh predmetov v učnih načrtih, kot v zborniku Kakšna sociologija razpravljajo Ferligoj, Štebe, Vehovar, Križnar in Hafner-Fink (Mlinar, 2015). V naši študiji se manko teh veščin odrazi kot razkorak med širokimi možnostmi napredne (primerjalne) analize, ki jih ponuja program SJM, ter njihovo dejansko izrabo. 


\section{Sklep}

Cilj študije je bil z analizo 1043 akademskih publikacij ovrednotiti infrastrukturno vlogo programa SJM pri produkciji družboslovnih spoznanj. V tej luči je poglavitna empirična ugotovitev, da podatke SJM uporabljajo analitiki na številnih disciplinarnih področjih, v vse večjem številu akademskih ustanov in ob tem obravnavajo širok razpon tematik praviloma v medčasovni perspektivi. Datoteke SJM tako predstavljajo pomemben del »ekosistema" družboslovnih kazalnikov v slovenskem prostoru. Zgodovinsko gledano imajo posebno vrednost podatki iz zgodnejšega, »socialističnega obdobja, ki predstavljajo specifično prednost za slovensko empirično družboslovje na posameznih področjih (Smrke, 2014: 272; Velikonja, 2014: 208; Fink-Hafner, 2004: 158) in ponujajo redko možnost empirične analize tega obdobja (Močnik, 2018: 87). Program SJM je tu v nacionalno dediščino prispeval številne empirične kazalnike, ki jih v drugih tranzicijskih državah ni. Tako je med drugim izmeril naraščajoči val nezadovoljstva ob nastopu jugoslovanske krize, dramatičen trend padca legitimnosti ZK, val osamosvojitvenih preferenc, učinek socialistične sekularizacije in nato tranzicijske desekularizacije, zgodovino stališč do razlik v dohodkih s kratkim tranzicijskim skokom; že v 70. letih je meril zaznave okoljskih problemov in v odslikal učinek Černobila na ekološka stališča in stališča o JEK itd. Vsebuje številne časovne serije, ki omogočajo opazovanje dinamike družbenih pojavov skozi več desetletij, kar analitiki s pridom izrabljajo. Ob tem je bila v zgodnejšem obdobju kakšna merska priložnost tudi zamujena, kar se recimo kaže v odsotnosti ali sporadični prisotnosti predtranzicijskih časovnih linij nekaterih danes standardnih družboslovnih »super kazalnikov«, kot so sreča, zadovoljstvo z življenjem in generalizirano zaupanje soljudem.

Neizkoriščene priložnosti so tudi na strani analitikov, verjetno največ prav na področju politologije in politične sociologije, saj bi predvsem prvo obdobje glede na svojo ekskluzivnost lahko predstavljalo večjo primerjalno prednost $\mathrm{v}$ mednarodnem publicističnem prostoru. Za drugo obdobje, ko prevlada mednarodni program s širokimi možnostmi modeliranja, pa se pokažejo vrzeli metodološkega znanja, saj analize podatkov ostajajo pretežno opisne. Manjkajo recimo zahtevnejše kvantitativne študije populizma v Sloveniji, ki so zelo številne pri analitikih raziskave ESS, saj gre za izrazit izziv evropskim in svetovnim demokracijam. Na manko kvantitativnih politoloških člankov v Sloveniji opozori tudi Schneider (2012: 134), Adam in Makarovič pa sta pred časom izpostavljala, da je ob »ogromni količini« empiričnih podatkov o stališčih do demokracije poglobljenih razprav o procesu demokratizacije, podprtih s temi podatki, zelo malo (Adam in Makarovič, 2002: 539). Podobno bi lahko rekli za tematiko priseljevanja, ki jo je SJM meril že globoko v času Jugoslavije in jo dandanes meri s teoretično 
podprtimi kazalniki ESS, a za slovenski prostor je zopet značilna pretežno deskriptivna analiza, pogosto osredotočena le na vidik socialne distance. Premajhno izkoriščenost podatkov programa SJM omenjata tudi Pahorjeva za področje zdravja in zdravstva in Dragoš v teoriji in praksi socialnega dela (v: Mlinar, 2015).

Precejšen poudarek v programski skici CJM je bil tudi na družbenem učinku oziroma temu, kar danes imenujemo podatkovna podpora odločevalcem in oblikovalcem politik, a tu naletimo na širšo in kompleksno problematiko (ne)učinkovitosti posredovanja in uporabe družboslovnih izsledkov drugim družbenim sistemom, ki ji na tem mestu ne moremo nameniti večjo pozornost. Podatke programa SJM smo sicer našli v večjem številu raziskovalnih in projektnih poročil, ki so praviloma namenjena širši strokovni javnosti (npr. poročila o človekovem razvoju, o civilni družbi, o javnem zdravju, integracijskih politikah za priseljence, neenakosti spolov), pa tudi v več strateških dokumentih in resolucijah Državnega zbora in Vlade RS (npr. Resolucija o nacionalnem planu zdravstvenega varstva 2008 2013, Resolucija o Nacionalnem programu za mladino 2013-2022, Resolucija o družinski politiki 2018-2028, Strategija Republika Slovenija v informacijski družbi, Program boja proti revščini in socialni izključenosti). To so vsekakor dobrodošli primeri, obenem pa ostaja dejstvo, da se je domača javnost veliko bolj odzivala na dnevnopolitične vsebine raziskav SJM kot pa na (teoretsko) utemeljene sociološke ali politološke vsebine (Hafner-Fink, 2016).

Nedvomno bi bila lahko akademska izraba programa SJM še večja in pridobiti vpogled $\mathrm{v}$ poglavitne uporabniške skupine je bil eden od ciljev pričujoče študije, ne nazadnje tudi za to, da se z boljšo komunikacijo zmanjša inflacija raziskovanja. Kot smo videli, velik del publikacij SJM vključuje tudi druge mikro podatke in $\mathrm{v}$ številnih primerih gre za primarne raziskave, ki so relevanten vir manjkajočih podatkov. Veliko pa je tudi primerov, ko diplomanti ali raziskovalci zbirajo primarne podatke dvomljive metodološke kakovosti, namesto da bi z manjšo spremembo raziskovalnega načrta svojo problematiko obravnavali na bistveno zanesljivejših podatkih nacionalnih raziskav in programov. Štebe $v$ tem smislu predlaga boljše vrednotenje analitičnega izkoriščanja podatkov ter ciljane razpise, ki bi spodbujali raziskave z uporabo obstoječih podatkov (2016). Vsekakor je dobra plat podatkov ta, da lahko počakajo tudi več desetletij, da jih uporabniki najdejo, saj njihova spoznavna vrednost s časom praviloma le še zraste. 


\section{Priloga 1: ORGANIZACIJSKA PRIPADNOST AVTORJEV V PUBLIKACIJAH S PODATKI PROGRAMA SJM}

\begin{tabular}{|l|c|}
\hline Organizacija & $\begin{array}{c}\text { Število prvih } \\
\text { avtorjev }\end{array}$ \\
\hline Univerza v Ljubljani - Fakulteta za družbene vede & 603 \\
\hline Univerza v Ljubljani - Filozofska fakulteta & 41 \\
\hline Univerza v Ljubljani - Fakulteta za socialno delo & 26 \\
\hline Univerza v Ljubljani - Medicina, zdravstvena nega, zdravstveni inštituti & 22 \\
\hline Univerza v Ljubljani - Fakulteta za šport & 17 \\
\hline Univerza v Ljubljani - Pravna fakulteta & 16 \\
\hline Univerza v Ljubljani - Ekonomska fakulteta & 11 \\
\hline Univerza v Ljubljani - Biotehniška fakulteta & 9 \\
\hline Univerza v Ljubljani - Pedagoška fakulteta & 9 \\
\hline Univerza v Ljubljani - Teološka fakulteta & 6 \\
\hline Univerza v Ljubljani - Druge fakultete & 6 \\
\hline & \\
\hline Univerza v Mariboru - Filozofska fakulteta & 44 \\
\hline Univerza v Mariboru - Fakulteta za varnostne vede & 31 \\
\hline Univerza v Mariboru - Ekonomska fakulteta & 8 \\
\hline Univerza v Mariboru - Pedagoška fakulteta & 3 \\
\hline Univerza v Mariboru - Pravna fakulteta & 2 \\
\hline Univerza v Mariboru - Druge fakultete & 4 \\
\hline Univerza na Primorskem & 20 \\
\hline Fakulteta za uporabne družbene študije & 17 \\
\hline Inštituti (IVZ /NIJZ, Mirovni inštitut, IJS, IER, INZ, INV...) & 54 \\
\hline & 26 \\
\hline Vlada RS, ministrstvo, urad vlade, državni zbor & 30 \\
\hline Slovenija - Drugo & 38 \\
\hline & \\
\hline Institucija v tujini & \\
\hline
\end{tabular}

Vir: Lastni prikaz.

\section{LITERATURA}

Adam, Frane in Matej Makarovič (2001): Tranzicijske spremembe v luči družboslovnih analiz. Teorija in praksa 38 (3): 373-385.

Adam, Frane in Matej Makarovič (2002): Sociology - Slovenia. V: M. Kaase, V. Sparschuh in A. Wenninger (ur.), Three social science disciplines in Central and Eastern Europe: handbook on economics, political science and sociology (1989-2001), 536-547. Berlin: Informationszentrum Sozialwissenschaften.

Adam, Frane (2016): Sociologija med ideologijo in kvantofrenijo. V: Zdravko Mlinar (ur.), Kakšna sociologija? Za kakšno družbo?, 86-90. Ljubljana: FDV in SAZU.

Andolšek, Stane (2016): Naloge sociologije in družbene spremembe v Sloveniji. V: Zdravko Mlinar (ur.), Kakšna sociologija? Za kakšno družbo?, 91-95. Ljubljana: FDV in SAZU. 
Andreß, Hans-Jürgen, Detlef Fetchenhauer in Heiner Meulemann (2019): CrossNational Comparative Research-Analytical Strategies, Results, and Explanations. KZfSS Kölner Zeitschrift Für Soziologie Und Sozialpsychologie 71 (S1): 1-28.

Bebler, Anton (2016): Sociologija vojske na Slovenskem. V: Zdravko Mlinar (ur.), Kakšna sociologija? Za kakšno družbo?, 188-193. Ljubljana: FDV in SAZU.

Bernik, Ivan (2016): V sociološkem labirintu. V: Zdravko Mlinar (ur.), Kakšna sociologija? Za kakšno družbo?, 255-258. Ljubljana: FDV in SAZU.

Broder, Živa in Rebeka Falle Zorman (2019): ESS fieldwork in Slovenia: nine rounds of building a successful interviewer network. Človek a spoločnost 22 (4): 63-66.

Engels, T., T. Ossenblok \& E. Spruyt (2012): Changing publication patterns in the Social Sciences and Humanities, 2000-2009. Scientometrics 93 (2): 373-390.

Fink-Hafner, Danica (2004): Slovenska politologija v spremenjenih domačih in svetovnih okoliščinah: priložnosti in nevarnosti. Demokratizacija, profesionalizacija in odpiranje v svet, Teorija in praksa 41 (1-2): 152-172.

Grizold, Anton (2014): Od akademskega dozorevanja do pogumnega vključevanja v svetovno znanstveno skupnost. Teorija in praksa 51 (6): 1013-1020.

Hafner-Fink, Mitja (2010): Program Slovensko javno mnenje v okviru mednarodnega družboslovnega anketnega programa ISSP. V: Niko Toš in Karl Müller (ur.), Primerjalno družboslovje: metodološki in vsebinski vidiki, 187-212. Ljubljana: FDV.

Hafner-Fink, Mitja (2016): Program Slovensko javno mnenje in 50-letnica institucionalizacije empiričnega raziskovanja na FDV. Teorija in praksa 53 (posebna številka): 5-8.

Hafner-Fink, Mitja (2016): Ali (enotna) družboslovna metodologija lahko prispeva k povezovanju družboslovnih disciplin? Raziskovalna izkušnja sociologa. V: Zdravko Mlinar (ur.), Kakšna sociologija? Za kakšno družbo?, 216-220. Ljubljana: FDV in SAZU.

Hopfenbeck, Therese, Jenny Lenkeit, Yasmine El Masri, Kate Cantrell, Jeanne Ryan in Jo-Anne Baird (2018): Lessons Learned from PISA: A Systematic Review of Peer-Reviewed Articles on the Programme for International Student Assessment, Scandinavian Journal of Educational Research, 62: 3, 333-353.

Jowell, Roger, Roberts Caroline, Fitzgerald Roty in Eva Gillian (2007): Measuring Attitudes Cross-Nationally. Lessons from the European Social Survey. London: Sage.

Kerševan, Marko (2014): Začetki delovanja Centra za proučevanje religije in cerkve 1966-1973 in sodelovanje z Zdenkom Roterjem. Teorija in praksa 51 (2/3): $232-243$.

Kozak, M., L. Bornmann in L. Leydesdorff (2014): How have the Eastern European countries of the former Warsaw Pact developed since 1990? A bibliometric study. Scientometrics 102 (2): 1101-1117.

Kuechler, Manfred (1998): The Survey Method: An Indispensable Tool for Social Science Research Everywhere?. American Behavioral Scientist 42 (2): 178-200.

Kulczycki, E., T. C. Engels, J. Pölönen, K. Bruun, M. Dušková, R. Guns... A. Zuccala (2018): Publication patterns in the social sciences and humanities: Evidence from eight European countries. Scientometrics 116 (1): 463-486. 
Malešič, Marjan (2013): Oris znanstvenega raziskovanja in razvoja izbranih disciplin na Fakulteti za družbene vede. Teorija in praksa 50 (2): 275-296.

Mlinar, Zdravko (1989): Lokalni odzivi na ekonomsko krizo. Teorija in praksa 26 (6/7): 713-726.

Mlinar, Zdravko (2004): Iz preteklosti za prihodnost v družbi in družboslovju: protislovnost vključevanja in izključevanja. Demokratizacija, profesionalizacija in odpiranje v svet. Teorija in praksa 41 (1/2): 9-66.

Mlinar, Zdravko (2016): Kakšna sociologija? Za kakšno družbo? Prispevki in izzivi sociologije na Slovenskem 1. Ljubljana: FDV in SAZU.

Mochmann, Ekkehard (2008): Improving the Evidence Base for International Comparative Research. International Social Science Journal 59 (193): 489-506.

Močnik, Rastko (2018): Nekaj shematičnih misli ob zborniku Kakšna sociologija? Za kakšno družbo?. Teorija in praksa 55 (1): 80-98.

Norris, Pippa (2009): The globalization of comparative public opinion research. V: T. Landmann and N. Robinson (ur.), The Sage Handbook of Comparative Politics, 520-540. Thousand Oak: Sage.

Saksida, Stane (2016): Od dogmatičnosti zgodovinskega materializma k empiričnemu sociološkemu raziskovanju. V: Zdravko Mlinar (ur.), Kakšna sociologija? Za kakšno družbo?, 77-80. Ljubljana: FDV in SAZU.

Schneider, C., D. Bochsler in M. Chiru (2012): Comparative Politics in Central and Eastern Europe: Mapping Publications over the Past 20 Years. European Political Science 12 (1): 127-145.

Smith, Tom (2019): Improving Multinational, Multiregional, and Multicultural (3MC) Comparability Using the Total Survey Error (TSE) Paradigm. V: P. Johnson, B. Pennell, I. Stoop and B. Dorer (ur.), Advances in Comparative Survey Methods: Multinational, Multiregional, and Multicultural Contexts, 13-44. Hoboken, NJ: Wiley.

Smrke, Marjan (2014): Proučevanje religije v centru s pečatom oporečništva. Teorija in praksa 51 (2/3): 261-283.

Štebe, Janez (1999): Izkoriščanje zapuščine slovenske empirične sociologije za današnje namene v okviru sekundarne analize. Družboslovne razprave 15 (30/ 31): $232-244$

Štebe, Janez (2016): Vsak konec pomeni tudi nov začetek: raziskovalna infrastruktura dostopa do podatkov. V: Zdravko Mlinar (ur.), Kakšna sociologija? Za kakšno družbo?, 216-220. Ljubljana: FDV in SAZU.

Štebe, Janez in Sonja Bezjak (2017): The case of Slovenian social science data infrastructure - ADP (Arhiv družboslovnih podatkov). V: Brina Malnar in Karl Müller (ur.), Societal enlightenment in turbulent times: a Festschrift for Niko Toš, 199214. Wien: Echoraum.

Toš, Niko (1995): Dozorevanje slovenske samozavesti. Dokumenti SJM. Ljubljana: FDV-IDV.

Toš, Niko (1999): Projekt Slovensko javno mnenje in njegov čas SJM 1968-1999. Družboslovne razprave 15 (30/31): 43-63.

Toš, Niko (2010): Longitudinalni projekt slovenskega empiričnega družboslovja: SJM 1966-2010. V: Niko Toš in Karl Müller (ur.), Primerjalno družboslovje: metodološki in vsebinski vidiki, 119-162. Ljubljana: FDV. 
Velikonja, Mitja (2014): Po sledeh in na novih poteh raziskovanja kulture in religij. Teorija in praksa 51 (2/3): 201-211.

Vovk, Tina in Slavko Kurdija (2019): Fieldwork experiences and monitoring techniques based on round 9 of the European Social Survey (ESS). Človek a spoločnost 22 (4): 67-73.

\section{VIRI}

CJMMK (1966): Predlog za ustanovitev CJM. Dostopno prek https://www.cjm.si/ wp-content/uploads/2021/04/Predlog-za-ustanovitev-CJM-1966.pdf, 21. 4. 2021.

CJMMK (1966a): Programsko-organizacijska skica centra za raziskovanje javnega mnenja v Sloveniji. Dostopno prek https:/www.cjm.si/wp-content/uploads/ 2021/04/Programsko-organizacijska-skica-CJM-1966.pdf, 21. 4. 2021.

Malnar, Brina (2021): Bibliografija programa Slovensko javno mnenje. Dostopno prek https://www.cjm.si/wp-content/uploads/2021/04/Bibliografija-programaSJM-1968-2021.pdf, 21. 4. 2021.

Malnar, Brina (2020): ESS annual bibliographic report. [Dostopano 21 april 2021] Dostopno prek https://www.europeansocialsurvey.org/docs/findings/ESSAnnual-Bibliographic-Report-2020.pdf, 21. 4. 2021. 